\title{
TREATMENT OF PNEUMONIA IN CHILDREN
}

\section{USE OF ORAL PENICILLIN IN OUT-PATIENTS}

BY

L. S. TAITZ,* M.B., B.Ch., B.Sc.

Senior House-Physician, Coronation Hospital, Johannesburg

AND

\author{
D. SLONE,* M.B., B.Ch. \\ Registrar, Coronation Hospital, Johannesburg
}

The use of oral preparations of penicillin in the successful treatment of pneumonia in adults and children has been reported (British Medical Journal, 1956 ; Austrian and Winstone, 1956; McWhorter et al., 1957). Because of the shortage of hospital beds, some cases of pneumonia in children have to be treated as out-patients. This necessitates daily attendance for procaine-penicillin injections. A study was undertaken to determine the efficacy of oral penicillin in the outpatient treatment of pneumonia in non-white (Coloured and African) children attending the Paediatric Department at Coronation Hospital, Johannesburg.

\section{Material and Methods}

Selection of Cases.-Cases were included in the study if they manifested dyspnoea in the presence of radiographic evidence of pneumonia. Sixteen cases showed lobar consolidation, eleven patchy consolidation, and six moderate but unequivocal loss of translucency in one or more lobes. Dyspnoea was evidenced by mobile ala nasi, tachypnoea, and subcostal recession. Most of the cases also had other signs of pneumonia, including pyrexia, dullness to percussion, and bronchial breathing, and crepitations. The absence of dyspnoea or radiographic changes automatically excluded cases from the series. Not all patients were considered suitable for out-patient treatment. Infants less than 3 months of age and those with cyanosis or cardiac failure were admitted to the wards.

Treatment.-All cases were treated with a suspension of phenoxymethyl penicillin (penicillin $\mathrm{V}$ ), containing $62.5 \mathrm{mg}$. per drachm (3.5 ml.), equivalent to 100,000 units. The dosage varied between $2 \mathrm{dr}$. $(7 \mathrm{ml}$.) fourhourly and six-hourly, depending on the age of the patient. The average case was treated with a total of $2 \mathrm{oz}$. $(60 \mathrm{ml}$.). During a period of one month 33 patients ranging between the ages of 4 months and 8 years were treated in this manner. Ten were under the age of 1 year. During this same period of time 24 cases of pneumonia were admitted to the wards.

\section{Results}

Seventeen cases $(52 \%)$ returned within one week of the initial visit and were found to be clinically cured (see Table). One patient returned after one month for an unrelated complaint showing no evidence of pneumonia. Ten patients did not return. An attempt was made to follow these up, and three were found to be perfectly well. The remaining seven were not traced. Thus, $63 \%$ of the series were known to be definitely cured. It is customary for all children

\footnotetext{
*Now at Department of Paediatrics, Baragwanath Hospital, Johannesturg.
}

attending this department not to return if they improve. Should death occur at home, certification is always requested. Furthermore, the poverty of this group largely precludes attendance by private practitioners. It can therefore be safely assumed that the remaining seven cases recovered, bringing the total to 29 recoverics $(87 \%)$.

One case was inadvertently given intramuscular penicillin, and is therefore excluded.

Four cases failed to respond to oral penicillin. Case 3, aged 6 months, appeared to respond to treatment but returned one month later with clinical and radiographic recurrence in the same lobe, which failed to respond to a second course of oral penicillin. Case 7 failed to respond to oral penicillin and was subsequently proved to be suffering from whooping-cough bronchopneumonia. Case 17 improved initially, but after nine

\begin{tabular}{|c|c|c|c|}
\hline \multicolumn{4}{|c|}{ Summary of Results } \\
\hline Age & $\begin{array}{l}\text { No. of } \\
\text { Cases }\end{array}$ & $\begin{array}{l}\text { No. of } \\
\text { Failures }\end{array}$ & Comment \\
\hline $\begin{array}{l}3-6 \text { months } \\
-12 \text { years } \cdots\end{array}$ & $\begin{array}{r}4 \\
6 \\
12\end{array}$ & $\begin{array}{l}1 \\
0 \\
2\end{array}$ & $\begin{array}{l}\text { One case resistant to penicillin } \\
\text { Nil } \\
\text { Failures found to have respectively }\end{array}$ \\
\hline $\begin{array}{llll}-8 & \end{array}$ & 11 & 1 & $\begin{array}{l}\text { Failure, subsequently developed Bell's } \\
\text { palsy }\end{array}$ \\
\hline
\end{tabular}

days relapsed and developed Bell's palsy. At this stage an $x$-ray examination of the chest showed complete resolution of the original lesion. The case was, however, treated with a broad-spectrum antibiotic. Case 24 failed to respond, and was subsequently proved to have pulmonary tuberculosis.

\section{Discussion}

Though oral penicillin has been shown to be effective in the treatment of acute pneumonia, its use in the treatment of out-patients has been restricted by fears of inadequate administration. In no case in this series could failure be attributed to this cause. It seems clear that even mothers in an unsophisticated population can be entrusted with the adequate medication of their children.

The presence of severe dyspnoea did not seem to make oral administration ineffective or difficult. Reactions to oral penicillin $\mathbf{V}$ were not encountered.

A notable feature in this series was the relative absence of relapses due to superinfection by penicillinresistant strains of organisms. Superinfection constitutes a major problem of in-patient treatment. This strongly suggests that out-patient treatment is the treatment of choice in all cases of pneumonia uncomplicated by severe anoxia or congestive cardiac failure.

\section{Summary}

Thirty-three cases of pneumonia in infants and children were treated as out-patients with phenoxymethylpenicillin, and $87 \%$ were clinically cured by this treatment.

It is suggested that out-patient treatment with oral penicillin is the method of choice in cases of mild and moderately severe cases of pneumonia.

We acknowledge the assistance given us in this study by Dr. Y. Yoffe and Dr. R. T. Katz, of the Department of Paediatrics, Coronation Hospital. We thank Dr. H. Falcke, senior paediatrician, and Dr. D. Elliot, superintendent of Coronation Hospital, for permission to publish these cases. 


\section{REFERENCES}

Austrian, R., and Winstone, A. L. (1956). Amer. J. med. Sci., 232, 624

Brit. med. J., 1956, 2, 1355.

McWhorter, H. B., Walker, W. F., Henry, R. B., jun., and Hamburger, M. (1957). Antibiot.'Ann., 1956-7, p. 300.

\section{PILOT HISTOPLASMOSIS SURVEY IN DELHII AREA}

BY

\section{R. VISWANATHAN, M.D., M.R.C.P.}

S. C. CHAKRAVARTY, M.B., M.S.

H. S. RANDHAwA, M.Sc.

AND

A. J. H. deMONTE, Dip.Bact.

Vallabhbhai Patel Chest Institute, University of Delhi, India

Clinical and epidemiological research during the past 12 years has demonstrated that histoplasmosis, caused by Histoplasma capsulatum, is one of the widely prevalent chronic pulmonary diseases in certain areas of the world. Before 1945 histoplasmosis was regarded as a fatal disease with widespread involvement of the reticulo-endothelial system. Now that the existence of a benign form of the disease is recognized, future epidemiological studies are bound to reveal its more extensive prevalence.

The widespread incidence of the benign primary form along the valleys of the Mississippi and Ohio rivers has been discovered by Christie and Peterson (1945) and by Palmer (1945). There is high incidence of positive reactors to histoplasmin in Mexico and Panama. It is also found to exist in Australia and in certain countries of northern Europe, but to a less extent.

Information regarding the prevalence of histoplasmosis in India is scanty. Wahi $(1952,1955)$ conducted a pilot survey in Agra with skin tests. He found 22 positive reactors to histoplasmin out of 1,331 people tested, giving $1.65 \%$ positives. Sen and Ghosh (1956), in a histoplasmin survey in Calcutta, found $0.67 \%$ positive reactors. Panja and Sen (1954) reported on "a unique case of histoplasmosis." Kalra et al. (1957) reported a case of histoplasmosis from Poona and claimed to have isolated the fungus and identified the same as Histoplasma duboissi. Recently Sen Gupta et al. (1957) have reported another case of histoplasmosis confirmed by culture.

The present pilot study was undertaken with a view to finding out the possible incidence of benign histoplasmosis in the Delhi area.

\section{Material and Methods}

Three areas were chosen for survey. One was in Alipur, a small village situated about 10 miles $(16 \mathrm{~km}$.) from Delhi. The second was in Nai Basti and Jumna Bazaar, which are situated on the bank of the River Jumna. The third area, which constitutes the urban area, was represented by patients attending the Municipal Tuberculosis Clinic and the Clinical Research Centre of the Chest Institute.

People tested were selected at random and belong to all age-groups above 5 years. The histoplasmin used for the survey was the one manufactured by Parke,
Davis \& Co. and supplied by the courtesy of the Technical Co-operation Mission of the U.S.A. $0.1 \mathrm{ml}$ of 1 in 100 dilution of the antigen was given intradermally on the forearm. All cases were simultaneously tuberculin-tested by intradermal injection of 5 T.U. of P.P.D. Readings were made 48 hours after the test. A reaction showing an induration measuring 5 by $5 \mathrm{~mm}$. or greater was taken as positive.

All available histoplasmin reactors were subjected to thorough physical, radiological, and laboratory examinations, which included complement-fixation test. blood culture, bone-marrow biopsy, and culture of bronchial aspirations. Sabouraud's glucose agar incubated at $25^{\circ} \mathrm{C}$. and brain-heart infusion blood-agar incubated at $37^{\circ} \mathrm{C}$. were used as media for culturing the fungus. The cultures were kept under observation for three to four weeks before they were discarded as negative for fungus. Examination for acid-fast bacilli was also done simultaneously.

\section{Results}

The results of skin-testing and examination of histoplasmin-positive reactors are summarized in Tables I and II. It will be seen from Table I that the

\begin{tabular}{|c|c|c|c|c|c|c|c|}
\hline \multirow{2}{*}{ Place } & \multirow{2}{*}{$\begin{array}{l}\text { No. } \\
\text { Tested }\end{array}$} & \multirow{2}{*}{$\begin{array}{l}\text { No. } \\
\text { Read }\end{array}$} & \multirow{2}{*}{$\begin{array}{c}\text { No. of } \\
\text { Histo- } \\
\text { plasmin } \\
\text { Posi- } \\
\text { tives }\end{array}$} & \multirow{2}{*}{$\begin{array}{c}\text { \% of } \\
\text { Histo- } \\
\text { plasmin } \\
\text { Posi- } \\
\text { tives }\end{array}$} & \multicolumn{2}{|c|}{$\begin{array}{l}\text { Response of Histo- } \\
\text { plasmin Positives } \\
\text { to P.P.D. Test }\end{array}$} & \multirow{2}{*}{$\begin{array}{c}\text { \%\%of } \\
\text { P.P.D. } \\
\text { Negative } \\
\text { Histo- } \\
\text { plasmin } \\
\text { Positive }\end{array}$} \\
\hline & & & & & $\begin{array}{l}\text { No. of } \\
\text { P.P.D. } \\
\text { Positives }\end{array}$ & \begin{tabular}{|c|} 
No. of \\
P.P.D. \\
Negatives
\end{tabular} & \\
\hline \multirow{3}{*}{$\begin{array}{l}\text { Delhi, } \\
\text { rural } \\
\text { Delhi, } \\
\text { riverine } \\
\text { Delhi, } \\
\text { urban }\end{array}$} & 112 & 103 & 3 & 2.9 & 3 & 0 & \multirow{3}{*}{$10 \%$} \\
\hline & 235 & 162 & 20 & $12 \cdot 3$ & 18 & 2 & \\
\hline & 400 & 301 & 15 & 4.9 & 15 & 0 & \\
\hline
\end{tabular}

TABLE II.-Results of Investigations on 26 Histoplasmin Reactors No. with no signs

$\begin{array}{lllll}\text { ", } & \text { multinle pulmonary calcifications } & . & . \\ \text { ", pulmonary calcifications and tuberculous lesions } & \text { ". } \\ \text { hilar enlargement only } & . . & . . & .\end{array}$

", positive histoplasma culture

highest percentage of histoplasmin-positive reactorsnamely, 12.3-was found among the population inhabiting Nai Basti and Jumna Bazaar areas. Even in the rural and urban areas our percentages for positive reactors are higher than those reported by Wahi in Agra and Sen and Ghosh in Calcutta.

During the course of another study which is being conducted in this institute, out of 30,000 chest $x$-ray films examined, 29 showed multiple pulmonary calcification without any evidence of any other disease in the lungs. Seven of these 29 were positive to the histoplasmin test. In the present study 17 out of 26 histoplasmin-positive reactors had multiple pulmonary calcifications.

The diagnosis of endemic histoplasmosis in a certain area will no doubt depend upon the four criteria laid down by Grayston and Furcolow (1956): (a) positive histoplasmin skin test, (b) positive histoplasmin serology, (c) development of miliary pulmonary calcification, and (d) isolation of Histoplasma capsulatum from the soil. Even though all the criteria have not been satisfied in the present survey, the significantly high percentage of histoplasmin-positive reactors and the not uncommon finding of multiple pulmonary calcification without any 